\title{
HEREIN OF "HEREIN GRANTED": WHY ARTICLE I'S VESTING CLAUSE DOES NOT SUPPORT THE DOCTRINE OF ENUMERATED POWERS
}

\begin{abstract}
Richard Primus*
INTRODUCTION

Article I of the United States Constitution begins as follows: "All legislative Powers herein granted shall be vested in a Congress of the United States[.]"1 That text is sometimes called the Vesting Clause, ${ }^{2}$ or, more precisely, the Article I Vesting Clause, because Articles II and III also begin with Vesting Clauses. ${ }^{3}$ And there is a feature of those three clauses, when compared, to which twenty-first century constitutional lawyers commonly attribute considerable significance. Although the three Clauses are similar in other ways, the syntax of Article I's Vesting Clause is not fully parallel to that of the other two. The Vesting Clauses of Articles II and III say, respectively, that "The executive Power shall be vested in a President of the United States of America" 4 and "The judicial Power of the United States, shall be vested in one supreme Court, and in such inferior Courts as the

* Theodore J. St. Antoine Collegiate Professor, The University of Michigan Law School. I thank Cade Boland, Ruby Emberling, Jonathan Gienapp, Kaley Hanenkrat, John Mikhail, Julian Mortenson, Virginia Neisler, William Treanor, Adam Wallstein, Audrey Springer-Wilson, and the participants in the 2019 University of Wisconsin Law School Constitutional Law Schmooze, organized by David Schwartz. Research for this Article was funded in part by the Cook Endowment at the University of Michigan Law School.

1. U.S. CONST. art. I, $\S 1$.

2. See, e.g., Eric A. Posner \& Adrian Vermeule, Interring the Nondelegation Doctrine, 69 U. CHI. L. REV. 1721, 1729 (2002) (using this nomenclature).

3. U.S. CONST. art. II, $\S 1$ ("The executive Power shall be vested in a President of the United States of America."); id. art. III, § 1 ("The judicial Power of the United States, shall be vested in one supreme Court, and in such inferior Courts as the Congress may from time to time ordain and establish.").

4. Id. art. II, $\S 1$.
\end{abstract}


Congress may from time to time ordain and establish." 5 They do not say that the President and the courts exercise the executive and judicial powers "herein granted."

Working from the intuition that that difference in language must be meaningful, several leading professors of constitutional law have adopted what I will call the enumerationist reading of Article I's Vesting Clause. ${ }^{6}$ According to the enumerationist reading, it matters that Article I's Vesting Clause speaks of powers "herein granted" rather than saying, in parallel with the other clauses, something like "The legislative power shall be vested in a Congress of the United States." To say "The legislative power shall be vested in a Congress of the United States," this line of thinking runs, would be to say that Congress enjoys legislative power in general. To say instead that Congress is invested with the "legislative powers herein granted," the argument continues, is to say that the legislative power granted to Congress is limited in a way that the executive and judicial powers granted to the other branches are not. Rather than exercising general legislative power, Congress is entitled to exercise only those legislative powers herein granted-that is, in the enumerationist understanding, those powers affirmatively specified in the text of the Constitution. ${ }^{7}$

A recent formulation of the point by Lawrence Lessig is illustrative:

5. Id. art. III, $\S 1$.

6. For a methodologically and politically diverse sample, see LAWRENCE LESSIG, Fidelity \& CONSTRAINT: HOW THE SUPREME COURT HAS READ THE AMERICAN CONSTITUTION 75 (2019); 1 LAURENCE H. TRIBE, AMERICAN CONSTITUTIONAL LAW 789 (3d ed. 2000) (“Article I, § 1 endows Congress not with 'all legislative power,' but only with the 'legislative Powers herein granted."'); Randy E. Barnett, The Continuing Relevance of the Original Meaning of the Thirteenth Amendment, 15 GEO. J.L. \& PUB. POL'Y 1, 4 (2017); Victoria Nourse, Reclaiming the Constitutional Text from Originalism: The Case of Executive Power, 106 CAL. L. REV. 1, 19 (2018); Nicholas Quinn Rosenkranz, Executing the Treaty Power, 118 HARV. L. REV. 1867, 1894 (2005).

7. This enumerationist reading of the Vesting Clause goes beyond what might be called the partial-power reading. On the partial-power reading, the fact that Article I, Section 1 speaks of "legislative powers," plural, rather than "legislative power"- the latter of which would be parallel to the language of Articles II and III-signals that Congress is vested with something less than plenary legislative jurisdiction. But that proposition alone does not entail the further proposition that the legislative jurisdiction with which Congress is vested is limited to the specific grants affirmed in the Constitution's text. It is the words "herein granted" that are commonly said to establish the latter proposition (and, thus, to reinforce the first one). The enumerationist reading takes the clause to establish both points. 
[T] he federal government, unlike state governments, has only the powers that are delegated to it by the Constitution. The Framers made this idea explicitly clear in Article I, where they wrote, "Congress has the powers herein granted." "Herein granted"-not any power you might imagine a government to have; just those powers specified in the Constitution. ${ }^{8}$

Note that in Lessig's presentation, the principle that Congress may exercise only the specific powers mentioned in the Constitution is not an inference from the text of the Vesting Clause. It is the plain meaning of the text: the language makes the point "explicitly clear."

But it doesn't. It doesn't even come close.

This Article explains why the Vesting Clause of Article I does not establish, or even support, the idea that Congress may exercise only its constitutionally enumerated powers. To be sure, that idea-for ease of reference, the enumeration principlemight be correct even if the Vesting Clause lends it no support. The enumeration principle might rest instead on the text of the Tenth Amendment, ${ }^{10}$ or the architecture of Article I, Section $8,{ }^{11}$ or a proposition about federalism, ${ }^{12}$ or a traditional understanding going back to the Founding. ${ }^{13}$ As it happens, and for reasons I have explained elsewhere, those other possible bases for the enumeration principle are also much weaker than commonly recognized. ${ }^{14}$ The project of this paper, however, is not to

8. LESSIG, supra note 6 , at 75.

9. Id.

10. U.S. CONST. amend. X ("The powers not delegated to the United States by the Constitution, nor prohibited by it to the States, are reserved to the States respectively, or to the people.").

11. See, e.g., Kurt T. Lash, "Resolution VI": The Virginia Plan and Authority to Resolve Collective Action Problems under Article I, Section 8, 87 NoTRE DAME L. REV. 2123 (2012) (arguing that the fact that Section 8 is written as a list of particular powers indicates that Congress does not have general legislative power).

12. See, e.g., Bond v. United States, 564 U.S. 211, 225 (2011) ("[A]ction that exceeds the National Government's enumerated powers undermines the sovereign interests of States.").

13. See, e.g., Nat'l Fed'n of Indep. Bus. v. Sebelius, 567 U.S. 519, 535 (2012) (opinion of Roberts, C.J.) (offering the traditional account on which the Framers wrote a Constitution without a Bill of Rights because they trusted the enumeration of congressional powers to do the work of limiting government).

14. See generally Richard Primus, The Limits of Enumeration, 124 YALE L.J. 576 (2014) (challenging structural, historical and textual rationales for the enumeration principle); Richard Primus, Why Enumeration Matters, 115 MICH. L. REV. 1 (2016) (offering an alternative account of the function that the enumeration principle plays in constitutional culture); Richard Primus, The Gibbons Fallacy, 19 U. PA. J. Const. L. 567 
challenge the enumeration principle as a whole. It is to attack, frontally and thoroughly, one of the supports on which that principle is said to rest. If the attack succeeds, perhaps readers will be more willing to consider the possibility that the enumeration principle's other supposed foundations are vulnerable as well. But even if readers are not inclined to doubt the enumeration principle more broadly, constitutional lawyers should not go around saying that the Vesting Clause establishes that principle. Because it does not.

In Part I of this Article, I expose problems with the enumerationist reading of Article I's Vesting Clause. Then, in Parts II and III, I offer better ways of understanding that Clause. In Part II, I show that if the nonparallel phrasing of the Constitution's three Vesting Clauses is to be given substantive legal significance, it makes more sense to read Article I's Vesting Clause as a statement that legislative power is vested solely in Congress than as a statement that Congress is limited to powers specifically enumerated. In Part III, I suggest that a yet better way to read the three Vesting Clauses is to accept that their nonparallel phrasing might not have any legal significance.

Two preliminary points are in order before proceeding further. First, the contrast between the language of Article I's Vesting Clause and that of Article II is commonly offered in support of two different propositions. One is that Congress can act only on the basis of specifically enumerated powers. The other is that the President, whose Vesting Clause does not speak of powers "herein granted," enjoys general executive power rather than just a collection of specific textual authorizations. ${ }^{15}$ My focus

(2017) (explaining that Chief Justice John Marshall's dictum in Gibbons v. Ogden that "[t]he enumeration presupposed something not enumerated" was not an endorsement of the enumeration principle); Richard Primus, "The Essential Characteristic": Enumerated Powers and the Bank of the United States, 117 MICH. L. REV. 415 (2018) (showing the contested status of the enumeration principle at the time of the First Congress); Richard Primus \& Roderick M. Hills, Jr., Suspect Spheres, Not Enumerated Powers: A Guide to Leaving the Lamppost, MICH. L. REV. (forthcoming) (explaining why it does not make sense to think that Article I's enumeration of congressional powers is a device for limiting federal legislative jurisdiction).

15. This view can encompass both what Julian Davis Mortenson calls the "law execution" theory of Article II, Section 1 (according to which the Article II Vesting Clause confers a general but substantive power to execute the law) and what Mortenson calls the "royal residuum" theory (according to which the Article II Vesting Clause confers a set of substantive powers once associated with the British Monarch, including such foreign affairs and war powers as are not expressly allocated to Congress). See Julian Davis Mortenson, Article II Vests the Executive Power, Not the Royal Prerogative, 119 Colum. 
in this Article is on the first of those propositions. But if I am right that Article I's Vesting Clause does not indicate that Congress is limited to a set of textually enumerated powers, then the contrast between the Vesting Clauses of Articles I and II does not support the claim that Article II vests general executive power in the President either. It might still be the case that the President should be understood to enjoy general executive power, but the contrasting language of the Vesting Clauses would not be a reason why. ${ }^{16}$

Second, the prominence of arguments based on the nonparallel phrasing of the Vesting Clauses seems to be a relatively recent phenomenon, dating more or less from the 1990s. Not that such arguments were completely novel at that time: as scholars of presidential power know, Alexander Hamilton used the contrast to defend President Washington's 1793 neutrality proclamation against the charge that the President had only those powers specifically enumerated in the Constitution. ${ }^{17}$ But Hamilton's argument seems to have been the product of post-ratification creativity, rather than the articulation of a generally shared understanding. As I will show below, the idea that Article I's Vesting Clause limits Congress to a set of textually enumerated powers was virtually unknown in the ratification debates of 1787$88 .^{18}$ It was also absent from the First Congress, and conspicuously so. The First Congress prominently featured conflict over the question of whether Congress was limited to powers specifically enumerated in the Constitution: think, for example, of the fight over chartering the Bank of the United States. The Representatives arguing for the enumerationist position in those debates had every incentive to point to the Vesting Clauses for support, if they thought the Vesting Clauses supported their view. None of them did, which suggests that none of them thought Article I's Vesting Clause established the enumeration principle. ${ }^{19}$ So Hamilton's 1793 argument indicates that it was possible for a smart lawyer in the Early Republic to hit upon this reading, but it

L. REV. 1169, 1180-83 (2019).

16. For further discussion of the Article II issue, see Julian Davis Mortenson, The Executive Power Clause, 168 U. PA. L. REV. 1269 (2020).

17. See Alexander Hamilton, Pacificus No. 1 (June 29, 1793), reprinted in 15 THE PAPERS OF AleXANDer HAmilton 33, 33-43 (Harold C. Syrett ed., 1969); see infra Part I.A.

18. See infra Part I.A.4.

19. See infra Part I.A.4. 
does not seem to have been an intuitive reading for the rest of the Founding generation.

Nor did American lawyers make contrasting the Vesting Clauses into a staple feature of constitutional argument after Hamilton showed them the way. A generation after Hamilton, Justice Joseph Story's Commentaries on the Constitution of the United States devoted roughly three thousand words to a chapter on Article I's Vesting Clause and at no point even hinted at the possibility that its text might bear on the scope of the powers vested in Congress ${ }^{20}$ and his discussions of the other Vesting Clauses include no mention of their being differently phrased.$^{21} \mathrm{I}$ am aware of only one case in the Constitution's first two centuries in which a federal court read Article I's Vesting Clause to support the idea that Congress can exercise only a set of textually enumerated powers. ${ }^{22}$ And in the law-review literature, it is hard to locate arguments from the non-parallel phrasing of the Vesting Clauses prior to the 1990s..$^{23}$ None of this means that the idea was ever wholly forgotten or affirmatively rejected..$^{24}$ But it does not

20. JOSEPH STORY, COMMENTARIES ON THE CONSTITUTION OF THE UNITED STATES §§ 269-88, at 199-209 (Boston, Hilliard, Gray \& Co. abr. ed., 1833). For Story, the thing worth discussing about the Vesting Clause was the bicameral nature of Congress. $I d$.

21. Id. §§ 720-65, at 515-45 (discussing Article II, Section 1); id. § 823, at 585, § 826, at 587-89 (discussing Article III, Section 1).

22. Kansas v. Colorado, 206 U.S. 46, 81 (1907). Similarly, I am aware of only two cases in which federal courts have read the contrast between the first two Vesting Clauses to support Hamilton's reading of Article II. They are Myers v. United States, 272 U.S. 52, 137-39 (1926) (citing Hamilton on executive power) and Goldwater v. Carter, 617 F.2d 697, 704 (D.C. Cir. 1979), vacated, 444 U.S. 996 (1979). To be clear, these are not the only two instances in which federal courts have grappled with the possibility that the Vesting Clause of Article II is a substantive grant of general executive power. They are merely the only occasions (to my knowledge) on which the contrast between the language of Article II's Vesting Clause and that of Article I has been presented as a reason to interpret either Vesting Clause in a particular way.

23. A 1988 article by David Currie seems to countenance the argument, but only in passing and in a footnote. See David P. Currie, The Constitution in the Supreme Court: 1946-1953, 37 EMORY L.J. 249, 289 n.240 (1988) (citing Hamilton).

24. Clinton Rossiter's 1961 edition of the Federalist Papers is probably best read to suggest an endorsement of the enumerationist reading of Article I's Vesting Clause, but it takes a bit of digging to see it. Rossiter printed the text of the Constitution at the back of his book. Next to the Constitution's text, he included, as a sort of index, the page number or numbers of the book on which Publius discussed the relevant constitutional language. Using this system, Rossiter indexed the words "All legislative Powers herein granted" to the portion of Federalist 45 where Madison described the powers of the national government as "few and defined." See THE FedERALIST PAPERS 529 (Clinton Rossiter ed., 1961). It seems fair to infer that Rossiter took the language of Article I, Section 1 to establish that Congress could exercise only a small number of specifically enumerated powers. But what the casual reader of Rossiter's index might not notice is that Federalist 
seem to have been commonly held either.

Things seem to have changed at roughly the same time that the Rehnquist Court was handing down landmark decisions like New York v. United States ${ }^{25}$ and United States v. Lopez. ${ }^{26}$ In 1994, in a Harvard Law Review article characterizing the entire modern administrative state as unconstitutional, Gary Lawson read the "herein granted" language of Article I, Section 1 to establish the enumerationist interpretation of that Vesting Clause. ${ }^{27}$ The following April, Laurence Tribe offered the enumerationist reading in another Harvard Law Review article, ${ }^{28}$ and Justice Clarence Thomas made the same move in his Lopez concurrence. ${ }^{29}$ Many others have adopted that reading in the quarter century since..$^{30}$

But it was not always thus. For most of American history, the language of Article I's Vesting Clause was not standardly given the enumerationist reading. Nor should it have been. The idea that Article I's Vesting Clause restricts Congress to a set of

45 nowhere quotes or mentions Article I, Section 1. (None of the Federalist Papers does.) The association between that Clause and the idea of a Congress whose powers are "few and defined" seems to be Rossiter's rather than Madison's.

25. 505 U.S. 144 (1992) (holding that Congress cannot commandeer state legislatures).

26. 514 U.S. 549 (1995) (holding, for the first time since 1937, that a piece of federal legislation exceeded Congress's legislative powers).

27. Gary Lawson, The Rise and Rise of the Administrative State, 107 HARV. L. REV. 1231, 1233-34 (1994). Lawson's article was published shortly after a set of authors endorsing robust presidential power revived Hamilton's 1793 point and adduced the contrast between the first two Vesting Clauses as evidence for their approach to Article II. See Steven G. Calabresi \& Kevin H. Rhodes, The Structural Constitution: Unitary Executive, Plural Judiciary, 105 HARV. L. REV.1153, 1175-76 (1992); Saikrishna Bangalore Prakash, Note, Hail to the Chief Administrator: The Framers and the President's Administrative Powers, 102 YALE L.J. 991, 997 (1993).

28. Laurence H. Tribe, Taking Text and Structure Seriously: Reflections on FreeForm Method in Constitutional Interpretation, 108 HARV. L. REV. 1221, 1269 (1995).

29. U.S. v. Lopez, 514 U.S. 549, 592 (1995) (Thomas, J., concurring). Justice Thomas has repeated the move more than once since Lopez, but always in separate opinions. See Zivotofsky ex rel. Zivotofsky v. Kerry, 135 S. Ct. 2076, 2097-98 (2015) (Thomas, J., concurring in the judgment in part and dissenting in part); United States v. Comstock, 560 U.S. 126, 160 (2010) (Thomas, J., dissenting).

30. See supra note 6. In caselaw rather than academic commentary, I am aware of only a few decisions clearly endorsing the enumerationist reading of Article I's Vesting Clause. See United States v. Ho, 311 F.3d 589, 596 (5th Cir. 2002): United States v. Bredimus, 352 F.3d 200, 204 (5th Cir. 2003) (citing Ho); United States v. Volungus, 599 F. Supp. 2d 68, 71 n.2 (D. Mass. 2009) (citing TRIBE, supra note 6), rev'd, 595 F.3d 1 (1st Cir. 2010). As noted above, Justice Thomas has offered the enumerationist reading in several separate opinions, but to my knowledge no Supreme Court majority has endorsed that interpretation since Kansas v. Colorado in 1907. 
textually enumerated powers cannot withstand careful scrutiny.

\section{THE ENUMERATIONIST READING}

According to the enumerationist reading of the Vesting Clause, "All legislative Powers herein granted shall be vested in a Congress of the United States" means that Congress can exercise only a specific subset of all legislative powers - those "herein granted"-rather than legislative power in general. In this Part, I show that this reading departs from the most straightforward meaning of the Clause's language and is in tension with the prevailing Founding understanding of constitutional structure. Prior to Hamilton's innovative argument in 1793, the idea that Article I's Vesting Clause limited Congress to a set of textually enumerated powers was essentially unknown. In other words, Americans at the time of the Constitution's ratification do not seem to have thought that Article I's Vesting Clause had the distinctive meaning that the enumerationist reading gives it, and for good reason.

\section{A. PROBLEMS}

\section{All and Only}

The threshold problem with the enumerationist reading is a matter of the ordinary-language meaning of the Vesting Clause's text. The enumerationist reading proceeds as if the Vesting Clause said "Only the legislative powers herein granted shall be vested in a Congress of the United States." If the Clause were worded that way, then it would indeed say, at least as a matter of ordinary language, that Congress can exercise no legislative powers except those granted "herein." But the word "only" does not appear in the Vesting Clause. Article I, Section 1 says that "All legislative Powers herein granted shall be vested in a Congress of the United States[.]" Not "only."

If the terms "all" and "only" are given their normal meanings, granting an institution all powers of a certain kind is not the same as granting it only those powers. Consider some ordinary-language analogies. "All men are mortal" does not mean that only men are mortal. More prosaically, if only my green socks are in the laundry, then my blue socks are not in the laundry. But if all my green socks are in the laundry, some of my blue socks 
might be there too. To come closer to the point, "All Bills for raising Revenue shall originate in the House of Representatives" 31 does not mean that the House is powerless to originate other kinds of bills. By the same token, Congress can be invested with all legislative powers of a given kind - those "herein granted" - and also be invested with other legislative powers. ${ }^{32}$

One should not overstate this point. The fact that the ordinary-language meanings of "all" and "only" function as described above does not mean that no text could use the word "all" to convey the restrictive meaning that "only" usually conveys. Language is more complicated than that. The meaning of a text is often different from the sum of the (literal, generally prevailing) meanings of the words it contains, taken one by one. And it is possible to identify uses of "all" and "only" that do not conform to the pattern I illustrated above. The phrase "all right" does not reliably signal that everything is as it should be, and E. M. Forster's injunction "Only connect!" 33 did not mean that connecting was the sole thing that people ought to do. So it is not impossible that a text using the word "all" could be properly read to mean the same thing that it would mean if the word "only" were used instead, if circumstances of context and audience understanding conspired to that end. And for many supporters of the enumerationist reading, the contrasting wording of the Constitution's three Vesting Clauses is just such a circumstance.

But an argument that a constitutional clause should be given a non-ordinary-language meaning should acknowledge the gap between the proffered meaning and the one that ordinary language would produce. The audience for the argument can then assess whether the reasons given in favor of the proffered meaning are strong enough to overcome whatever presumption exists in favor of ordinary language. And as it happens, proponents of the enumerationist reading of Article I's Vesting Clause do not usually argue that the Vesting Clause establishes the enumeration principle even though the most straightforward reading of its text says something else. On the contrary, they seem not to notice that the Clause has an ordinary-language meaning different from the one they favor. Some leading proponents of the

31. U.S. CONST. art. I, \& 7, cl. 1.

32. See John Mikhail, The Constitution and the Philosophy of Language: Entailment, Implicature, and Implied Powers, 101 VA. L. REV. 1063, 1081 (2015).

33. E.M. FORSTER, HOWARDS END 188 (1910). 
enumerationist reading even contend that the enumeration principle simply follows from the text of the Vesting Clause: in Lessig's formulation, that the text of the Clause makes the principle "explicitly clear." ${ }^{34}$ Needless to say, it doesn't. As a matter of ordinary language, the text of the Clause does not establish the enumeration principle. It doesn't even suggest it.

To be sure, the Vesting Clause does not establish that Congress has powers beyond those specifically enumerated. Taken in isolation, an ordinary-language understanding of the text is consistent with Congress's having "all legislative powers herein granted" as well as some other powers, and it is also consistent with Congress's having "all legislative powers herein granted" but none others. That the text is consistent with either possibility is precisely the point. Despite the widespread acceptance of the enumerationist reading, the text of Section 1 does not say that Congress is limited to powers "herein granted." The possibility of limitation is not addressed at all.

\section{Where is "Herein"?}

So far, the analysis has assumed, as the enumerationist reading does, that "herein granted" in Article I means "granted in this document." But it is worth pausing for a moment to note two other possibilities. The first is that "herein granted" means "granted in this Article," not "granted in this document." The second is that "herein granted" means-or at least meant, in 1787-not "granted in this document" but "granted in this system of government." If either of those alternatives is correct, the enumerationist reading cannot be right.

Consider first the possibility that "herein granted" means "granted in Article I." As a matter of textual interpretation, there is no reason why reading the language that way is less compelling than reading it to mean "granted anywhere in this document." "Herein" lacks resolving power as between those options. The word appears at the very beginning of Article I, which is a natural place for a statement about things that will happen in Article I particularly. On the other side of the question, one might argue that the text also appears at the beginning of the whole document, which is a natural place for a statement about things that will happen in the whole document. But that response is less than

34. See LESSIG, supra notes 6 and 8 and accompanying text. 
clean, because Article I's Vesting Clause does not, in fact, appear at the beginning of the whole document. The Preamble does. The language of the Preamble is reasonably understood as intended to give the reader a frame for understanding the entire document in a way that the language in a particular Article-even Article I, Section 1-might not.

I do not think that this Preamble problem, or anything else, dispositively proves that "herein granted" must mean "granted in Article I" rather than "granted in this document as a whole." 35 But "granted in Article I" is certainly a plausible reading-perhaps even a marginally more plausible one, considered solely as a textual matter. So without purporting to have shown that "granted in this document as a whole" is an incorrect reading, I suggest that the existence of this alternative should at least create uncertainty.

The significance of that uncertainty is straightforward. If "All legislative Powers herein granted" means "All legislative powers granted in Article I," then the Vesting Clause would not bespeak a limitation on the legislative powers of Congress, even if "all" were read to mean "only." Congress obviously has legislative powers granted outside of Article I. Consider the power to declare the punishment of treason, which is granted in Article III,$^{36}$ or the power to legislate for the federal territories, which is granted in Article IV,${ }^{37}$ not to mention all the powers granted in the enforcement clauses of later constitutional Amendments. ${ }^{38}$ So if "All legislative Powers herein granted" means "All legislative powers granted in Article I," the Vesting Clause cannot mean "Congress is vested with the powers herein granted and no others."

For some readers, that consequence will simply be a reason to reject the possibility that "herein granted" means "granted in Article I." The more confident one is that the enumerationist reading is correct, the more it will make intuitive sense to give the words of the Vesting Clause a meaning that will support that reading, rather than one that will undermine it. But note that what

35. A third possibility-that it means "granted in this Section"-can be safely rejected on the grounds that the text of the Section in question specifies no particular powers of Congress.

36. U.S. CONST. art. III, § 3, cl. 2.

37. Id. art. IV, $\S 3, \mathrm{cl} .2$.

38. See, e.g., id. amend. XVI (power to levy income taxes). 
is doing the work when such a reader rejects the possibility that "herein" means "in Article I" is not the text of the Clause. It is a preexisting conviction about what the Clause must mean. If, instead, one asked what the Clause might mean by consulting its text, the correctness of the enumerationist reading would not be at all clear.

Next, consider a different kind of alternative-one that rests not on the common-sense meaning of the words of the Clause to a twenty-first-century reader but on a feature of American constitutional thought in 1787-88. Then as now, the term "constitution" might refer not to a specific document but to a system of government, one within which a document like the one we call "the Constitution" might or might not play a role. ${ }^{39}$ One can accordingly speak of the "American constitution" as a mostly stable but somewhat fluid system of institutions and practices and documents and understandings, on the model of the British constitution the Founders knew, rather than as a single specified document. ${ }^{40}$ That much is well understood. Regardless of what legal consequences they think might or might not follow from the conceptual point, many modern constitutional theorists are comfortable talking about these two kinds of constitutionssometimes called the big-C Constitution, meaning the document with the proper name, and the small-c constitution, which is the broader system. But most of the time, theorists who speak of these two $\mathrm{C} /$ constitutions see them as just that: two different entities, each reflecting a different sense of the term that names them both. ${ }^{41}$

That sense of a clear distinction between the document and the system has not always been so solid. As Jonathan Gienapp has explained at length, many Americans in 1787-88 drew no sharp

39. See, e.g., Christopher G. Tiedeman, The UnWritten Constitution of THE United STATES (1890); Richard Primus, Unbundling Constitutionality, 80 U. CHI. L. REV. 1079 (2013); SANFORD LEVINSON, CONSTITUTIONAL FAITH (1988). In saying that a constitution can be a system of government, I do not mean to deny that things other than governments also have constitutions, in the relevant sense of the term. But the present discussion is about the governmental kind.

40. See, e.g., K.N. Llewellyn, The Constitution as an Institution, 34 CoLUM. L. REV. 1 (1934).

41. See, e.g., Thomas C. Grey, The Constitution as Scripture, 37 STAN. L. REV. 1 (1984) (arguing for the importance of distinguishing between those portions of constitutional law that are textual and those that are not); Ernest A. Young, The Constitution Outside the Constitution, 117 YALE L.J. 408 (2007) (recognizing both kinds and sharply distinguishing between the two). 
distinction between the document and the constitution's other components. ${ }^{42}$ All of it - the document, the traditional practices, the background assumptions and shared understandings - was just "the constitution." In Gienapp's telling, the idea of the written Constitution as a more fully differentiated entity-not necessarily the exclusive source of constitutional authority, but at least a distinct unit of analysis - gained prominence in the $1790 \mathrm{~s} .{ }^{43}$ But in 1787-88, it was not the prevailing conception. (The modern convention of using "Constitution" to refer to the document and "constitution" to refer to the broader system was accordingly not in use at the Founding, not only because eighteenth-century capitalization conventions were different, but also because Americans then might have felt less need for a way to make the distinction.)

So when the Framers wrote in the Preamble that they were ordaining and establishing "this Constitution," Gienapp suggests, they meant to be ordaining and establishing something broader than the document in which those words appeared. They meant that they were ordaining and establishing a constitution in the broader, more fluid, systemic sense. ${ }^{44}$ The promulgation of the document was, within that way of thinking, an act announcing a new constitution, but the constitution so announced was not limited to the document. It was the broader thing. Just as Article II or Article IV was not the entire constitution, neither was the document as a whole.

For the purposes of the present inquiry into the Vesting Clause, the significance of Gienapp's point is that the Framers might have understood "herein granted" to mean "granted in this constitutional system," not "granted in this document." 45 The domain of "herein," after all, depends on the unit of analysis that is used to delimit the scope of "here." "Herein" in a document organized like the Constitution is organized could mean "in this Clause," "in this Section," "in the Article," "in this document," and perhaps other things as well, with the best reading dependent

42. See Jonathan Gienapp, The Second Creation: Fixing the American CONSTITUTION IN THE FOUNDING ERA (2018).

43. E.g., id. at 197-200, 330-32.

44. See Jonathan Gienapp, The Myth of the Constitutional Given: Enumeration and National Power at the Founding, 69 AM. U. L. REV. F. 183 (2020); Jonathan Gienapp, The Unfounded Originalist Constitution, 39 L. \& HIST. REV. (forthcoming Feb. 2021) (on file with author).

45. See supra note 44 . 
on the broader context. (We know that "herein" in Article I, Section 1 does not mean "in this Section" not because the word could not bear that meaning but because if it did, the "powers herein granted" would be an empty set.) Gienapp's analysis indicates that the list of increasingly broad possible meanings of "herein" does not end at "in this document," because for the Framers the document was not sharply differentiated from the rest of the constitution.

Put differently: the reason why it is intuitive to modern readers that "herein granted" means "granted in this document" is that our intuitive answer to the question "Where do those words appear?" is "in the Constitution," by which we mean neither more nor less than "in the document." But an American in 1787-88 who said "those words appear in the C/constitution" could easily have meant that those words were part of the larger system. If the document is not separate from the rest of the constitution, then it is perfectly natural to think that when the document says any particular thing, it need not be significant that it's the document talking. What's talking is the constitution. And if the constitution speaks of powers "herein granted," it is speaking of powers granted in the constitution, which is something broader than the document.

Within the Founding-era conceptual scheme that Gienapp identifies, the enumerationist reading of the Vesting Clause makes little sense. After all, the enumerationist reading requires the "legislative powers herein granted" to be limited to legislative powers specified in the text. If the "legislative powers herein granted" can include legislative powers that are vested in Congress by virtue of nontextual aspects of the constitution - say, by virtue of the sheer fact that Congress was the national legislature ${ }^{46}$ or by virtue of the fact that no other institution within the system could fulfill a needed function ${ }^{47}-$ then the text of the

46. See, e.g., Alexander Hamilton, Final Version of an Opinion on the Constitutionality of an Act to Establish a Bank (Feb. 23, 1791), in 8 THE PAPERS OF AlEXANDER HAMILTON 97, 100 (Harold C. Syrett ed., 1965) (describing certain powers as "resulting" to Congress in this way); 2 ANNALS OF CONG. 1955 (1791) (statement of Rep. Vining) (arguing that Congress could exercise certain powers simply by virtue of its being the legislature of an independent nation); id. at 1905 (statement of Rep. Ames) (same).

47. See, e.g., 2 ANNALS OF CONG. 1955 (1791) (statement of Rep. Vining); id. at 1929 (statement of Rep. Smith). See also Missouri v. Holland, 252 U.S. 416, 433 (1920) ("[I]t is not lightly to be assumed that, in matters requiring national action, 'a power which must belong to and somewhere reside in every civilized government' is not to be found." 
Vesting Clause does not limit Congress to any set of textually enumerated powers. That text could still indicate that Congress is vested only with those powers resulting to it from some specific feature of the constitutional system, of course - or at least, it could so indicate if "all" were read to mean "only," in the way described above. But the core claim of the enumerationist reading is that Congress is restricted to powers affirmatively specified in the written Constitution. If "herein granted" means something broader than "granted in this document," that reading falls apart.

\section{Congress Might Have Nonlegislative Powers}

The foregoing difficulties with the enumerationist reading are matters of close textual reading. Next, consider an important problem that is a matter of constitutional structure. The problem, in short, is that the enumerationist reading only makes sense if all of Congress's powers are legislative. The point of the enumerationist reading, after all, is to establish that Congress can only do things that the text specifies. It reads the Vesting Clause to limit Congress's "legislative powers" to a certain set, and it makes the assumption that limiting Congress's legislative powers is the same thing as limiting Congress. But if Congress has nonlegislative powers as well as legislative ones, then a principle limiting Congress's legislative powers would not function as a general limit on congressional power. Congress could still have other powers, including powers not textually enumerated, so long as those powers are not legislative powers.

Modern readers tend to overlook this possibility. The dominant tendency today is to regard the powers exercised by Congress - which we call "the legislative branch" - as "legislative powers," and the powers exercised by the President as "executive powers," and the powers exercised by the courts as "judicial powers." But that way of thinking flattens out what is better understood as - and what the Founders clearly understood as - a more complex system. ${ }^{48}$

(quoting Andrews v. Andrews, 188 U.S. 14, 33 (1903))).

48. On Founding-era recognition of this complexity, see, e.g., PAULINE MAIER, RATifiCATION: THE PEOPLE DEBATE THE CONSTitution, 1787-1788, at 57, 151, 286, 365 (2010). See also 1 ANNALS OF CONG. 554 (1789) (Joseph Gales ed., 1834) (statement of Rep. Jackson) ("Are the Legislative, Executive, and Judicial powers kept separate and distinct [under the new Constitution]? No, Mr. Chairman, they are blended; not, to be sure, in so high or dangerous a degree, but in all the possible forms they are capable of receiving; 
The power to impeach and remove government officers, for example, is not legislative in any substantive sense, even if undertaken by a body that we think of as the "legislature." The impeachment process is a matter of prosecuting and adjudicating the case of a single individual - that is, an exercise of powers that are executive and judicial in nature-rather than a process of lawmaking. ${ }^{49}$ The Senate's role in the appointment process is also not a lawmaking role. ${ }^{50}$ Congress's power to lay taxes ${ }^{51}$ seems unproblematically legislative, but its textually specified power to collect taxes ${ }^{52}$ might be better understood as executive. ${ }^{53}$ Congress's power to call conventions for considering constitutional amendments on the application of the state legislatures $^{54}$ is at least as plausibly executive as legislative: the decision to hold a convention belongs to the state legislatures, and Congress is tasked merely with making it happen.

Given the malleability of the category, "legislative power," some of these characterizations are surely contestable. ${ }^{55} \mathrm{It}$ is not my view that any judgment about these contestable claims is as good as any other. All things considered, I think the idea that all

the Executive has a qualified check upon the Legislature; the Legislature exercises the powers of the Judiciary and Executive.").

49. See, e.g., 1 ANNALS OF Cong. 463-64 (1789) (Joseph Gales ed., 1834) (statement of Rep. Madison) (describing the Senate's power to try impeachments as judicial).

50. See, e.g., Richard Henry Lee's Proposed Amendments (Sept. 27, 1787), in 1 THE DOCUMENTARY History OF THE RATIFICATION OF THE CONSTITUTION 337, 338-39 (Merrill Jensen ed., 1976) [hereinafter 1 DHRC] (characterizing the Senate's power of appointments as executive); 1 ANNALS OF CONG. 496 (1789) (Joseph Gales ed., 1834) (statement of Rep. Madison) (same).

51. See U.S. CONST. art. $1, \S 8, \mathrm{cl} .1$.

52. Id.

53. In 1783, when the Confederation Congress considered a report on the proposed impost, some members of Congress argued that the word "levy" in the report should be changed to "collect." Their reason was "that the first word imported a legislative idea, \& the latter an executive only, and consequently the latter might be less obnoxious to the States." See 25 JOURNALS OF THE CONTINENTAL CONGRESS, 1774-1789, at 945-46 (Gaillard Hunt ed., 1922) [https://perma.cc/73R3-EV4W]. The motion to alter the wording was defeated, but not on the ground that "levy" and "collect" lacked the different senses that proponents of the change identified. Opponents of the change seem to have raised the possibility that nothing would turn on the difference in wording but to have rested more heavily on the view that the word choice was significant and that "levy" was the more appropriate term. See id.

54. See U.S. CONST. art. V.

55. Indeed, as the discussion below highlights, the proposition "the Constitution gives Congress non-legislative powers" depends on contestable claims about not just the meaning of "legislative powers" but also about the meaning of "Congress." (The same is true for the proposition "the Constitution does not give Congress any non-legislative powers."). 
of Congress's powers are legislative in nature is either hard to sustain or else devoid of meaningful content. I recognize, however, that my view rests in part on an exercise of judgment and that some reasonable people will judge differently. As a result, the conclusion to this piece of the analysis is perhaps best stated in conditional form: if in the end it makes sense to say that the Constitution confers at least one nonlegislative power on Congress, then it cannot make sense to say that Congress can exercise no powers except the "legislative powers herein granted." After all, it would then be the case that Congress is entitled to exercise powers that are not legislative at all.

As a prescriptive matter, one might think that a system of government ought to prevent any institution from exercising more than one of these kinds of power. On the basis of examples including some of those given above, many Antifederalists during the ratification debates criticized the Constitution as violating the separation-of-powers principle, because it jumbled powers and branches rather than confining each branch of government ("the legislature," "the executive") to the exercise of powers bearing the cognate name ("legislative power," "executive power"). For example, Richard Henry Lee argued in September 1787 that the proposed Constitution improperly vested an executive power in the legislative branch by authorizing the Senate to confirm presidential appointments. ${ }^{56}$ Responding to such criticisms, Madison argued that a judicious mixture of the powers was consistent with the separation-of-powers idea, which at bottom required not that an institution could never be vested with more than one kind of power but that each branch should have the ability to check and balance the others. ${ }^{57}$ But the fact that the

56. See 1 DHRC, supra note 50, at 338. Lee proposed to solve this problem by assigning the confirmation power to a privy council lodged entirely within the executive branch. Id. For other examples, see MAIER, supra note 48, at 151, 286.

57. See, e.g., THE FEDERALIST No. 47 (James Madison) ("One of the principal objections inculcated by the more respectable adversaries to the Constitution, is its supposed violation of the political maxim, that the legislative, executive, and judiciary departments ought to be separate and distinct. ... I persuade myself, however, that it will be made apparent to every one. that the charge cannot be supported, and that the maxim on which it relies has been totally misconceived and misapplied.... [The true principle is not] that these departments ought to have no partial agency in, or no control over, the acts of each other.... [But] that where the whole power of one department is exercised by the same hands which possess the whole power of another department, the fundamental principles of a free constitution are subverted.... This, however, is not among the vices of that constitution. The magistrate in whom the whole executive power resides cannot of himself make a law, though he can put a negative on every law; nor administer justice in 
Constitution did not maintain a strict one-to-one pairing of institutions with types of power was common ground between the Constitution's defenders and its detractors. What they disputed was whether the mixture was vice or virtue. And if the Constitution vests Congress with nonlegislative powers, then it cannot be true that Congress's only powers are the "legislative powers herein granted."

To be sure, someone willing to read "all" to mean "only" could argue that the Vesting Clause limits Congress to the legislative powers herein granted where the exercise of legislative power is concerned. In other words, even if Congress can exercise some legislative powers and also some nonlegislative ones, it might be the case that the legislative powers Congress can exercise are only the ones "herein granted." Again, this position would require reading the Clause as if it said "only" rather than "all." But perhaps as great a problem for someone tempted by this argument is that it abandons the proposition that Congress is limited to a set of textually enumerated powers. If the Vesting Clause limits only the subset of congressional powers deemed "legislative," then Congress can exercise powers beyond those "herein granted" so long as those powers are denominated executive, judicial, or anything else other than legislative, whether on prevailing modern conceptions or within the eighteenthcentury schemes the Founders knew. A lot of power lies down that road, including a lot of power going beyond anything specified in the text of the Constitution. So if the ultimate aim is to support the view that Congress can exercise only a set of textually enumerated powers, this refinement will be of no help.

A different response in defense of the enumerationist reading might maintain that, although the Constitution blends forms of power within particular institutions, no part of the mixand-match arrangement vests a nonlegislative power in Congress. One critical element of this rejoinder is a distinction between powers vested in Congress and powers vested in the Senate or in the House of Representatives. On this view, the power to confirm appointments is a power of the Senate,$^{58}$ not a power of Congress as a whole. Similarly, the text of the Constitution does not say that "Congress" has the power to impeach and remove government

person, though he has the appointment of those who do administer it.").

58. See U.S. CONST. art. II, § 2, cl. 2. 
officers. It says that the House of Representatives has the power of impeachment ${ }^{59}$ and that the Senate has the power to try impeachments. ${ }^{60}$ The House alone is not "Congress," and neither is the Senate. So if impeachment and trial are two separate powers, one vested in the House and one in the Senate, then it is plausible to say that neither of these nonlegislative powers is vested in Congress as such.

How persuasive this rejoinder seems is partly a matter of one's relative tastes for formal and substantive reasoning. Substantively, nothing that either House does in an impeachment process has legal consequences without the action of the other, such that the power to remove an officer is held only by the two branches acting together-that is, by Congress. Formally, however, the text of the Constitution speaks of impeachment and trial as two powers vested in two separate bodies, neither of which is "Congress." Indeed, someone inclined to read the Constitution as vesting only legislative powers in Congress might argue that the vesting of these three nonlegislative powers (confirmation, impeachment, and trial) in one House or the other rather than in Congress as a whole testifies to the Constitution's general commitment to restrict Congress as such to a single sort of power: the legislative sort.

I am not aware that anyone at the Founding offered the distinction between Congress and its separate chambers in order to establish that the Constitution vested no nonlegislative powers in Congress. But for modern readers motivated to defend that position, the distinction may be cogent enough to be serviceable even if nobody at the Founding thought in those terms. Moreover, readers motivated to defend that position are also likely, and in good faith, to be able to solve other problems that distinguishing between Congress and its component Houses might seem to threaten. For example, the power to originate bills for raising revenue is vested in the House of Representatives alone. ${ }^{61}$ So if the idea that Congress possesses only "legislative powers" requires the premise that a power vested in one House is not a power vested in Congress, and if it is also the case (as the plain

59. See id. art. I, § 2, cl. 5 ("The House of Representatives ... shall have the sole Power of Impeachment.").

60. See id. art. I, § 3, cl. 6 ("The Senate shall have the sole Power to try all Impeachments.").

61. Id. art. I, § 7, cl. 1 . 
text of Article I, Section 1 provides) that all legislative powers are vested in Congress, then it must be the case that the power to originate bills is not a legislative power. Absent the stakes of this interpretive question, that proposition might be a tough sell. But if one finds it appealing (or imperative) to conclude that Congress exercises only legislative powers, and one recognizes that defending that conclusion requires classifying the power to originate revenue bills as nonlegislative, it will not be difficult to come up (in good faith) with arguments characterizing the power to originate bills as nonlegislative. For example, one might argue that "legislative power" is exercised only when a bill is approved and not at any earlier point in the process.

But that possibility raises this further puzzle: approved by whom? Presumably the answer is "approved by the body with the power to make the bill a law." That answer need not imply that Presidents exercise legislative power when signing bills, because congressional approval is sufficient to make a bill a law even if the President does nothing. ${ }^{62}$ But it does seem to indicate that Congress does not exercise legislative power when, acting under Article V, it votes to propose constitutional amendments, because proposed amendments do not have the force of law until ratified by state legislatures. The problem, then, is that if the origination of a bill by the House is not legislative because it is insufficient to give the bill the force of law, the proposal of an amendment is also not legislative. And the proposal of amendments is a power vested in Congress as such. ${ }^{63}$

As the preceding discussion illustrates, the contention that the Constitution vests no nonlegislative powers in Congress is

62. Id. art. I, § 7, cl. 2-3.

63. One could also deny that the authority to originate bills for raising revenue and the authority to propose constitutional amendments to the states are legislative powers on the grounds that they are not "powers" at all, because the Constitution does not use that word when describing those processes. See id. art. I, § 7, cl. 1 ("All Bills for raising Revenue shall originate in the House of Representatives[.]"); id. art. V ("The Congress, whenever two thirds of both Houses shall deem it necessary, shall propose Amendments to this Constitution ... which ... shall be valid to all Intents and Purposes, as Part of this Constitution, when ratified by the Legislatures of three fourths of the several States[.]"). One's sense of the strength of that argument may depend on one's taste for formal as opposed to substantive reasoning. But if one accepts this argument, it would seem to follow that even if Congress were limited to "powers herein granted," that limitation would not prevent Congress from possessing the capacity to do many things not lying within those powers, so long as those capacities were not called "powers." The enumerationist reading aims at something more substantively constraining than that. 
partly enabled by the fact that the categories "legislative," "executive," and "judicial" are malleable. ${ }^{64}$ Consider again Congress's power to call conventions for proposing constitutional amendments on the application of the state legislatures. ${ }^{65}$ If we are disposed to think of all congressional action as "legislative," it will not be hard to think of Congress's calling such a convention as a legislative action. Calling a convention is prospective, and it has a policymaking aspect, and it would likely create rules for many people to follow, perhaps by determining the process for selecting delegates or the convention's rules of procedure. But it is also easy to see calling such a convention as an executive action. It is the states and not Congress who possess the authority to make the substantive decision about whether to hold a convention. ${ }^{66}$ Congress's role is limited to putting that choice into practice. To be sure, Congress in calling such a convention could exercise considerable discretion, for example, in setting the time and place of the convention and perhaps in crafting its rules of procedure or even providing for the method by which delegates would be chosen. Through those decisions, Congress could exercise substantive influence on the convention it was calling. But such discretion and influence are common in many activities that the American system routinely considers "executive." ${ }^{67}$ So if we see the Constitution as containing a fair amount of mixing and matching with respect to powers and branches, as many in the

64. As are other categories that might be deployed to describe kinds of governmental power. For example, Americans who followed Locke's analysis would have deemed several congressional powers "federative" rather than "legislative." See JOHN LOCKE, SECOND TREATISE OF GovernMENT, §§ 146-48, at 76-77 (C. B. Macpherson ed., 1980) (1690). According to one recent Supreme Court opinion, Locke's approach to the separation of powers was particularly influential among the Founders. See Gundy v. United States, 139 S. Ct. 2116, 2133-34 (2019) (Gorsuch, J., dissenting). If so, and if as a result the Founders would have understood several congressional powers as "federative" rather than legislative, then at least those Founders would have been unlikely to think that Congress was limited to "legislative powers herein granted." There is good reason to think, however, that Locke's view of the separation of powers was not influential in the American Constitution-making process. See, e.g., 1 THE RECEPTION OF LOCKE's POLITICS, at 1-liii (Mark Goldie ed., 1999); John Dunn, The Politics of Locke in England and America in the Eighteenth Century, in JOHN LOCKE: PROBLEMS AND PERSPECTIVES 45, 45-80 (John W. Yolton ed., 1969).

65. See U.S. CONST. art. V ("The Congress ... on the Application of the Legislatures of two thirds of the several States, shall call a Convention for proposing Amendments[.]").

66. See id. ("The Congress ... on the Application of the Legislatures of two thirds of the several States, shall call a Convention for proposing Amendments[.]") (emphasis added).

67. Think of the discretion exercised by prosecutors, or by the President as Commander-in-Chief. 
Founding generation did, then it is easy to see the power to call conventions on the application of state legislatures as executive. And if Congress is vested with an executive power, then the proposition that Congress is vested only with the "legislative powers herein granted" cannot be correct. ${ }^{68}$

Perceptive observers have long understood that the classification of a given power as "legislative," "executive," or "judicial" is often contestable, ${ }^{69}$ and sometimes the wisest conclusion is that a given power does not fall inherently and exclusively into a single one of those categories. ${ }^{70}$ Different readers may thus have different intuitions about whether the Constitution's blending of powers and branches undermines the enumerationist reading of Article I's Vesting Clause. A reasonable person could conclude that the Constitution (on either a Founding-era reckoning or a modern one) does not clearly vest "executive," "judicial," or other "nonlegislative" powers in "Congress" as such. Alternatively, a reasonable person could conclude that the Constitution does that very thing, whether with respect to impeachment or appointments or calling conventions or otherwise. ${ }^{71}$ So in the end, the most responsible thing that can

68. One might resist the conclusion that the power to call conventions is an executive power vested in Congress by denying that Congress's calling a convention is an exercise of a power at all: Article V says that Congress "shall call a convention," not that Congress has the power to call a convention. Again, this move rests a great deal on terminology, and again it raises the problem that on its terms, even if Congress were limited to the "powers herein granted," it might have untold abilities to do other things, so long as the capacity to do those things was called something other than "powers."

69. See, e.g., THE FEDERALIST No. 37 (James Madison).

70. See, e.g., THE Federalist No. 75 (Alexander Hamilton) (reaching this conclusion with respect to the treaty power).

71. Based on his reading of Blackstone, William Winslow Crosskey concluded that as many as thirteen of the powers that Article I assigned to Congress were powers held by the King within the British constitutional system and would have been considered "executive" rather than legislative in nature. See 1 William Winslow CROSSKEY, POlitics AND THE CONSTITUTION IN THE History OF THE UNITED STATES 411-14 (1953); see also Michael W. MCCONnEll, THE President WHO Would Not BE King (unpublished manuscript) (on file with author) (endorsing this position). These included the powers to coin money, to declare war, to issue letters of marque and reprisal, to raise and regulate fleets and armies, to naturalize foreigners, to be the "arbiter of commerce," and to regulate weights and measures. See CROSSKEY, id. at 412-14. That view likely overstates the degree to which the Founders thought the Constitution assigned executive powers to Congress: Julian Mortenson cautions that, within the then-prevailing understanding of British constitutional law, powers could be formally vested in the King without being "executive powers" in any substantive sense. See Mortenson, supra note 15. It is not my purpose here to adjudicate this dispute. But I will point out, on Mortenson's side of the question, that Americans in the 1780s who criticized the Constitution for vesting executive power in the legislative branch did not, so far as I am aware, point as examples 
be said on this matter is conditional: if the category "legislative powers" does not exhaust the category "congressional powers," it would make little sense to think that Article I opens with a declaration that a particular subset of legislative powers - that is, the "legislative powers herein granted"--were the only powers that Congress could exercise. Indeed, if the Founders generally understood the Constitution to vest both legislative and nonlegislative powers in Congress, then reading the Vesting Clause as if it said that Congress could exercise only the legislative powers herein granted would not just be to read the Clause to mean something that the language does not say. It would be to read the Clause to mean something that its language does not say in order to make the Clause say something that the Founders, or many of them, would have regarded as false.

\section{Original Usage: The Inference from Silence}

Another piece of Founding-era evidence is considerably less ambiguous. As far as can be determined, the enumerationist reading of the Vesting Clause was virtually unknown at the Founding. It was not, to be sure, completely unavailable. A great many people made a great many arguments about the Constitution in 1787-88, and, as in any sprawling conversation, a wide variety of ideas was on offer-some of them more tenable than others. But as far as I can tell, the surviving records reveal only two instances during the ratification period when anyone read Article I, Section 1 to mean that Congress could exercise only powers specifically enumerated in the Constitution's text. ${ }^{72}$ A delegate named Stephen Chambers read the clause that way at the Pennsylvania ratifying convention, ${ }^{73}$ and so did the

to most of the powers on Crosskey's list of thirteen. It is also worth noting that any conclusion about how many non-executive powers the Constitution vested in Congress requires not just judgments about what counts as a nonlegislative power but also about what counts as "one power." (How many powers are articulated in Article I, Section 8, clause 1?) For present purposes, however, nothing substantive depends on how many nonlegislative powers the Founders thought the Constitution assigned to Congress. All that matters is whether the Founders, or many of them, regarded Congress as exercising at least one power that was not "legislative" in nature.

72. This is my conclusion based on searching, inter alia, the DHRC database for the term "herein granted" on May 31,2019, and subsequently asking a research assistant to try to falsify my conclusion using a variety of search strings.

73. The Pennsylvania Convention (Dec. 1, 1787), in 2 The Documentary History OF THE RATIFICATION OF THE CONSTitution 444, 445 (Merrill Jensen ed., 1976). Chambers, who was one of the original members of the Pennsylvania Society of the 
pseudonymous writer Cassius in the Massachusetts Gazette. ${ }^{74}$ Perhaps the argument was also made on other occasions: the documentary record is imperfect, and I could have missed some examples that the record does reflect. But regardless of whether the idea was articulated on just two occasions or also on four or five others, it would not have been more than marginal in the continental conversation. Apparently, the enumerationist reading was neither natural enough to be common nor persuasive enough on the few occasions when it was articulated for others to pick it up and make use of it.

It is hard to know just why Americans at the Founding did not offer the enumerationist reading of the Vesting Clause. But there is no shortage of possibilities, as the argument of this Article to this point suggests. Maybe they did not think that "herein granted" meant "granted in this document." Or if they did think the powers referred to were specified in the document, maybe they took "herein granted" to mean "granted in Article I," in which case the Clause was obviously not limiting, given the congressional powers specified in places like Article IV. ${ }^{75}$ Maybe they understood that no limit on "legislative powers" could be a limit on congressional power in general, because Congress had nonegislative powers as well as legislative ones. Maybe they just didn't think that "all" meant "only." But for whatever reasons, and in whatever combinations, it seems clear that Americans at the Founding did not understand the Vesting Clause in the way the enumerationist reading does. Which should probably not be surprising, given that reading's several weaknesses.

The enumerationist reading's near-total absence from the

Cincinnati, was an Irish-born lawyer who came to Pennsylvania before the Revolution. He died in 1789 as a result of a duel fought for apparently non-political reasons. See William Henry Egle, The Federal Constitution of 1787, 11 PA. MAG. HIST. \& BIOGRAPHY at 69, 6970 (1887).

74. Cassius VI, To the Inhabitants of this State, MASS. GAZETTE, Dec. 18, 1787, reprinted in 5 THE DOCUMENTARY HISTORY OF THE RATIFICATION OF THE CONSTITUTIOn 479, 482 (John P. Kaminski \& Gaspare J. Saladino eds., 1998); Cassius VI, To the Inhabitants of this State, MASS. GAZETTE, Dec. 25, 1787, supra, at 511, 511. Cassius was probably James Sullivan, a justice of the highest court in Massachusetts from 1776 to 1782 and, in 1787, one of the lawyers who defended participants in Shays's Rebellion, as well as Governor of Massachusetts from 1807 to 1808. See 4 THE DocumENTARY History OF THE RATIFICATION OF THE CONSTITUTION 30 (John P. Kaminski \& Gaspare J. Saladino eds., 1997); MAIER, supra note 48, at 193-94; CHARLES WARREN, 1 HISTORY OF THE HARVARD LAW SCHOOL AND OF EARLY LEGAL CONDITIONS IN AMERICA 188 (1908).

75. See, e.g., U.S. CONST. art. IV, § 3, cl. 2 (power to legislate for the territories). 
ratification process is particularly noteworthy because issues about the extent of congressional power were central to the debate. The Constitution's opponents repeatedly charged that Congress in the new system would be able to wield whatever power it wanted. ${ }^{76}$ The Constitution's defenders denied the charge many times. ${ }^{77}$ If the very first words of Article I clearly stated that Congress had less than general legislative authority, why did the Constitution's defenders not say so, loudly and often? Even if the first words of Article I were just a plausible suggestion of the point, rather than a clear statement of it, it would have been natural for the Constitution's defenders to invoke it in these arguments. But they didn't. In all of the Federalist Papers, for example, thirty or so of which specifically addressed questions about the extent of congressional power, Publius invoked the Vesting Clause exactly zero times.

The evidence from the First Congress points in the same direction. ${ }^{78}$ Questions about enumerated powers were central to, and extensively debated in, both the removal debate of $1789^{79}$ and the debate on the bill to establish the Bank of the United States in $1791 .^{80}$ In the House of Representatives, each of those debates lasted for several days, with prominent Founders laying out their views about enumerated powers under the Constitution. On many occasions, it would have been useful for some of them (including Madison, both times) to be able to say that the text of the Constitution restricted Congress to the exercise of enumerated powers. In the removal debate, an argument that the Vesting Clause of Article I is limiting in a way that the Vesting Clause of Article II is not would have let Madison and his allies bolster their contention that the Constitution vested the President with executive power in general, rather than only with a specified list of powers. ${ }^{81}$ But the distinctive text of Article I's Vesting Clause

76. See, e.g., Brutus I, To the Citizens of the State of New York, N.Y.J., Oct. 18, 1787, reprinted in 13 THE DOCUMENTARY HISTORY OF THE RATIFICATION OF THE Constitution 411, 414 (John P. Kaminski \& Gaspare J. Saladino eds., 1981); Centinel II, To the People of Pennsylvania, PHILA. Freeman's J., Oct. 24, 1787, id. at 457, 460.

77. See, e.g., THE FEDERALIST Nos. 41, 45 (James Madison).

78. See generally Joseph M. Lynch, Negotiating the Constitution: The EARLIEST DEBATES OVER ORIGINAL INTENT (1999).

79. See GIENAPP, supra note 42, at 125-63.

80. See id. at 202-47.

81. See, e.g., 1 AnNALs OF CONG. 495-97 (1789) (Joseph Gales ed., 1834) (statement of Rep. Madison). The point can be further sharpened, because Madison in this debate actually did invoke the Constitution's three Vesting Clauses as part of his argument that 
played no role in the removal debate. So far as appears in the records, nobody mentioned it at all.

The Bank debate is even more germane, because it focused above all else on questions about the extent of congressional power. Madison spoke repeatedly and at length, arguing not just that Congress could exercise only its enumerated powers but also that the principle of a limiting enumeration was fundamental to the system. ${ }^{82} \mathrm{He}$ needed to argue these points, because not everyone agreed. Some of Madison's opponents conceded that Congress could exercise only its enumerated powers and disagreed with Madison only on the question of whether the enumerated powers authorized the Bank, but others denied the basic premise that Congress could exercise only the powers that the Constitution specifically enumerated..$^{83}$ If any significant number of members of the First Congress had thought that Article I, Section 1 decided this issue in Madison's favor, someone - likely Madison - would have said so. But in the entire debate, at no point did Madison or anyone else arguing for the limitation of congressional power point to the language of the Vesting Clause.

As far as I have been able to determine, the first prominent endorsement of the enumerationist reading of the Vesting Clause came two years after the Bank debate. As noted in the Introduction to this Article, Hamilton in 1793 wrote a series of essays contending that President Washington had unilateral authority to proclaim America's neutrality in the war between Britain and France. Writing under the pseudonym "Pacificus," Hamilton developed several arguments. One was that issuing a neutrality proclamation was an "executive act" and that the Constitution vested the President with "the executive power"meaning, on Hamilton's account, not just a set of specified powers (to command the army and navy, to receive ambassadors, etc.) but executive power in general. ${ }^{84}$ To support that claim, Hamilton

the Constitution manifests an intention to minimize the extent to which power of any given kind (e.g., "legislative") would be assigned to a branch not bearing the cognate description (e.g., "the legislature"). Id. at 497. So the Vesting Clauses were plainly in view-and yet neither Madison nor anyone else made use of the nonparallel phrasing of the Clauses, even though it would have helped them to do so.

82. See, e.g., Primus, "The Essential Characteristic," supra note 14.

83. See, e.g., id.

84. Alexander Hamilton, Pacificus No. 1 (June 29,1793), reprinted in 15 THE PAPERS of AleXANDER HAmilton 33, 33-43 (Harold C. Syrett ed., 1969). 
contrasted the language of Article I's Vesting Clause with that of Article II. The difference between "All legislative Powers herein granted shall be vested" and "The executive Power shall be vested," Hamilton contended, reflected the difference between conferring a specific set of enumerated powers and conferring a type of power categorically. ${ }^{85}$ This was, of course, exactly the argument that would have helped Madison during the removal debate four years earlier. But Madison did not come up with it. And an argument that Madison could not come up with in 1789 is unlikely to have been a straightforward Founding-era understanding of the Constitution.

Hamilton's use of the Vesting Clause argument in his Pacificus essay is well known. ${ }^{86}$ For a modern audience, it likely masks the fact that the argument was all but unheard of before 1793. When a lawyer knows that a constitutional interpretation that is widely credited today was made by Hamilton, it is easy to jump to the conclusion that it was a standard view at the Founding - or at least a view known and taken seriously. But as described above, the enumerationist reading of the Vesting Clause was all but unknown during the ratification debates and in the First Congress, despite the prominence during those times of debates about the extent of congressional power. Against that background, Hamilton's articulation of the view in 1793 seems like innovative lawyering by an attorney for the executive branch.

That doesn't make it wrong. Reading creatively is part of what good lawyers do. For present purposes, though, the point is that Hamilton's argument in 1793 required lawyerly creativity. He was not simply producing the straightforward meaning of the text in a way that his audience would recognize as familiar. Hamilton's arguing for this reading in 1793 thus does not establish that the Framers or the ratifying public would have shared his view in 1787-88, and they do not seem to have done so. Nor is there any indication that Hamilton himself had that view until the assignment to justify Washington's proclamation motivated him to go looking for useful arguments.

Just as the innovative nature of Hamilton's argument doesn't

85. Id.

86. See, e.g., Zivotofsky ex rel. Zivotofsky v. Kerry, 135 S. Ct. 2076, 2101 (2015) (Thomas, J., concurring in the judgment in part and dissenting in part) (invoking Hamilton's Pacificus argument); Eric. A Posner \& Adrian Vermeule, Legislative Entrenchment: A Reappraisal, 111 YALE L.J. 1665, 1675 n.26 (2002) (same). 
make that argument wrong, it also doesn't make that argument right. Of the many innovative arguments that creative lawyers make, something less than a hundred percent turn out to be sound. And when Hamilton did argue from an enumerationist interpretation of the Vesting Clause, it is not clear that he thought the matter all the way through. For example, Hamilton did not explain why a text that says "All legislative Powers herein granted shall be vested in a Congress of the United States" should mean "Only the legislative powers herein granted shall be vested in a Congress of the United States." Or how a Constitution widely understood to mix types of power across the branches could also be a Constitution limiting Congress to legislative power alone.

\section{B. CONFIRMATION BIAS}

Hamilton's failure to engage the problems with his reading might not have been the product of deliberate evasion. It is ordinary, in the process of creative lawyering, for an advocate to find a text that looks supportive at first glance and run with it, attending insufficiently to the weaknesses of his interpretation. When we want a text to mean something, we sometimes read it to mean that thing in perfectly good faith, even if a less motivated or more critical reader could give good reasons why the text should not be read that way.

The popularity of the enumerationist view of Article I's Vesting Clause among modern constitutional lawyers may be at least partly explained in similar terms. Just as we tend to misread texts to say what we want them to mean, we tend to misread texts to say what we expect them to mean. ${ }^{87}$ Almost every constitutional lawyer has a clear expectation that the Constitution will say that Congress can exercise only its enumerated powers. Every law student learns that principle. So there is a tendency to read the text of the Constitution as if it confirmed the point. And sure enough, two features of the Vesting Clause do correspond to features of the idea that Congress can exercise only specifically enumerated powers. First, the enumerated-powers idea indicates that Congress exercises specific powers, plural, rather than legislative power in general-and the Article I Vesting Clause, unlike its Article II and III counterparts, speaks of "powers" rather than "power." Second, the enumerated-powers idea insists

87. See Richard Primus, Constitutional Expectations, 109 MICH. L. REV. 91 (2010). 
that Congress can do only things that are affirmatively specified in the Constitution, and the language of "herein granted" might reflect the idea of affirmative specification in the constitutional text. For a reader who is primed to think that the Constitution promulgates the enumeration principle, these features of the Vesting Clause's text might be enough to confirm the presupposition. This is probably all the more so for readers who take the enumeration principle to be, conceptually, the first fundamental thing that one must know about the constitutional powers of Congress. After all, the Vesting Clause isn't just some stray clause in Article I. It is the first thing the Constitution says about Congress. What more appropriate way could there be for the Constitution to begin its discussion of Congress than with a statement of the essential and distinctive characteristic of congressional power-that is, that it is confined to the powers specifically enumerated?

The trouble with the thought process just described is that it gives in too easily to confirmation bias. The reader already believes that the Constitution permits Congress to authorize only its specifically enumerated powers. The reader expects an announcement of that principle when the subject of Congress is introduced. The first Clause describing Congress has some textual features that seem to distinguish Congress's power from the President's and the judiciary's, and it has some words that resonate with the enumerated-powers idea. So the reader concludes that the enumerated-powers idea is what animates the language of the Clause. In so doing, the reader does not notice that that the plain meaning of the text says something else. And because the meaning the reader has attributed to the text is satisfying, the question of whether Americans in 1787-88 understood (or could have understood) the text this way probably does not arise. ${ }^{88}$ It is assumed-much as most modern lawyers simply assume that the Founders understood "thirty-five years" to mean what we mean by the same phrase. Except that the assumption in the latter case is warranted.

Nothing I have argued above means that the enumeration principle is wrong. Maybe that idea is correct, such that constitutional lawyers are fully justified in approaching their work on the understanding that Congress can exercise only its textually

88. "What satisfies the conscience lulls the mind." Llewellyn, supra note 40 , at 10. 
specified powers. ${ }^{89}$ But even if that were the case, it would not follow that every clause of the Constitution should be read to establish or confirm that rule. The clause providing that Senators are elected every six years ${ }^{90}$ has no bearing on whether Congress is limited to a set of enumerated powers. Neither does the Privileges and Immunities Clause of Article IV ${ }^{91}$ or the Debts Clause of Article VI. ${ }^{22}$ The point of the present analysis is that the Vesting Clause of Article I does not bear on the question either. That constitutional lawyers who expect the Constitution to establish the enumeration principle would find it established by the Vesting Clause is explicable, partly as a matter of confirmation bias. But whether or not the enumeration principle is a sound principle of constitutional law, the Vesting Clause does not establish it.

\section{THE ABSENCE OF Alternatives}

One other factor may help support the enumerationist reading of the Article I Vesting Clause: the absence of an alternative. Given the conventions of constitutional interpretation, the difference in syntax between the Vesting Clause of Article I and the Vesting Clauses of Articles II and III presents the conscientious interpreter with a question. Why is this Vesting Clause different from those other Vesting Clauses? Once the question is asked, the interpreter wants an answer. The enumerationist reading offers one. So, if the enumerationist answer is the only answer available, interpreters might gloss over its shortcomings. The only available answer is, by definition, the best available answer.

But the enumerationist answer is not the only way to explain the distinctive syntax of Article I's Vesting Clause. It is merely the most familiar. In the next two sections, I describe two other explanations, each of which is better than the enumerationist answer. The first alternative answer operates at the level of plain textual meaning: it makes sense of the difference in phrasing between Article I, Section 1 and the other two Vesting Clauses on a straightforward reading of the Constitution's language. The second alternative answer operates at the level of drafting history.

89. Again, I have my doubts. See supra note 14. But that isn't the point right now.

90. See U.S. CONST. amend. XVII.

91. See id. art. IV, § 2, cl. 1 .

92. See id. art. VI, cl. 1. 
It suggests that the nonparallel wording of the three Vesting Clauses is a contingent artifact of the Constitution's drafting process and reflects nothing substantive about congressional power. Different readers may have different intuitions about the relative attractiveness of these two explanations, but either one should be enough to displace the enumerationist reading.

\section{THE PLAIN-MEANING READING}

In this Part, I describe a different way to read Article I's Vesting Clause. It is a plain-meaning reading - that is, a reading that gives the words of the Clause their ordinary-language senses. This way of reading the Clause has both strengths and weaknesses. In the end, I suspect that the attractiveness of this way of reading the Clause is partly a function of how committed one is to the proposition that the difference in phrasing between Article I's Vesting Clause and that of the other two Vesting Clauses must reflect something substantive in constitutional law. For readers who are comfortable with the idea that the difference in phrasing among the Vesting Clauses might have no substantive significance, the plain-meaning reading (like the enumerationist reading) might seem less than compelling. But if the difference in phrasing must have substantive significance, then there is a strong case for adopting the plain-meaning reading - a stronger case, certainly, than the case for adopting the enumerationist reading.

\section{A. WHAT THE WORDS SAY}

Consider what the Vesting Clause would mean if its words were given their ordinary sense. On a plain-meaning approach, "All legislative Powers herein granted shall be vested in a Congress of the United States" means, well, that all legislative powers granted in the Constitution are vested in Congress. In other words, if the Constitution grants a legislative power, the body in which that power is vested is Congress. ${ }^{93}$ Not the President, not the courts, not the states, not the people directly. Just Congress. ${ }^{94}$

93. This formula works if "the Constitution" refers to a document, and it also works if "the Constitution" refers to a system. In the latter case, the passage means that all legislative powers granted by this system of government are vested in Congress. See supra notes $42-43$ and accompanying text.

94. This plain-meaning reading does not establish a strong form of the nondelegation doctrine, because the fact that Congress is "vested" with a power need not mean that 
This plain-meaning reading supplies a straightforward answer to the question of why Article I's Vesting Clause differs in syntax from the other two Vesting Clauses. From a Founding-era perspective, if the Constitution vested all legislative power in a single branch of the national government, then it treated legislative power differently from executive power and judicial power. As noted above, it was common ground within the Founding generation that the national executive power was not vested entirely in the President, nor the national judicial power entirely in the courts. Examples included the House's and Senate's executive and judicial powers in the impeachment process $^{95}$ and the Senate's executive power in confirming appointments. ${ }^{96}$ In the First Congress's first serious encounter with separation-of-powers issues - the removal debate of 1789Madison accordingly characterized the Vesting Clause of Article II as a default rule that is sometimes overcome by specific constitutional provisions varying the general pattern. ${ }^{97}$ In other words, "The executive Power shall be vested in a President" did not mean that all executive power would be vested in the

Congress is disabled from delegating that power to another decisionmaker. See Thomas W. Merrill, Rethinking Article I, Section 1: From Nondelegation to Exclusive Delegation, 104 COLUM. L. REV. 2097, 2097 (2004) (noting that the text of the Vesting Clause could reflect either the position that Congress may not delegate legislative power or the position that only Congress may delegate legislative power, and concluding overall that the latter position is superior); Julian Davis Mortenson \& Nicholas Bagley, Delegation at the Founding (Univ. of Mich. Pub. Law Research Paper No. 658, 2019), https://ssrn.com/abstract=3512154 (adducing Founding-era support for the permissibility of Congress's delegating the exercise of its powers to other actors, provided that Congress retained the authority to end the delegation and exercise the relevant power itself). In delegation cases, the Supreme Court has associated Section 1 with the nondelegation doctrine. See, e.g., Whitman v. Am. Trucking Ass'n, 531 U.S. 457, 472 (2001) ("Article I, $\S 1$, of the Constitution vests '[a]ll legislative Powers herein granted ... in a Congress of the United States.' This text permits no delegation of those powers[.]"). As Merrill's argument indicates, that association might be incorrect-and indeed one can read the Supreme Court's language in American Trucking as hedged on the point. "This text permits no delegation" is, strictly speaking, consistent with "nor does it prohibit delegation." But whether or not Section 1 establishes a strong form of the nondelegation doctrine, reading its text as a limitation of certain legislative powers to Congress alone is more defensible, as a matter of plain meaning, than reading it as a limitation of Congress to a specific set of enumerated powers.

95. See, e.g., 1 ANNALS OF CONG. 463-64 (1789) (Joseph Gales ed., 1834) (statement of Rep. Madison) (describing the Senate's power to try impeachments as judicial).

96. See, e.g., 1 DHRC, supra note 50 (characterizing the Senate's power as executive); 1 ANNALS OF CONG. 496 (1789) (Joseph Gales ed., 1834) (statement of Rep. Madison) (same).

97. 1 Annals of Cong. 496 (1789) (Joseph Gales ed., 1834) (statement of Rep. Madison). 
President. It couldn't mean that, because some executive power was $n o t$ vested in the President..$^{98}$

On this understanding, the distinctive syntax of Article I's Vesting Clause simply reflects the fact that legislative power, unlike executive and judicial power, was vested exclusively in a single branch of the national government. The Constitution could not say "All executive powers herein granted shall be vested in a President" or "All judicial powers herein granted shall be vested in one Supreme Court and such inferior courts as Congress may from time to time ordain and establish," because those propositions would have been false. Some executive powers were located outside the "executive branch," and some judicial powers were located beyond the "judicial branch." But legislative powers were not vested in any body other than Congress. So it was appropriate for Article I's Vesting Clause to say that "All legislative powers herein granted" were vested in Congress.

This plain-meaning interpretation makes sense of the fact that Article I's Vesting Clause speaks of "All legislative powers" while the other Vesting Clauses speak of "The executive power" and "The judicial power." But if the plain-meaning reading is to be an attractive alternative to the enumerationist reading of the Vesting Clause, it would benefit from also explaining something else: why Article I's Vesting Clause contains the words "herein granted." If the point of the Clause were to say that only Congress was vested with legislative powers, Article I could have opened with the words "All legislative powers shall be vested in a Congress of the United States" rather than "All legislative Powers herein granted shall be vested in a Congress of the United States."

But it is not hard to imagine rationales for the choice to include the "herein granted" language that make sense within a plain-meaning reading of the clause. One possibility, acknowledged by the Supreme Court in 1792, is that the words "herein granted" reflected the view that the power of establishing (or disestablishing) the Constitution was itself legislative in

98. See also 1 ANNALS OF CONG. 487 (1789) (Joseph Gales ed., 1834) (statement of Rep. Jackson) (explaining the President obviously does not have all of the executive power under the Constitution). Yes, this means that Justice Scalia was wrong in his rhetorically magnificent dissent in Morrison v. Olson, 487 U.S. 654 (1988) (Scalia, J., dissenting) (insisting that the text of the Vesting Clause of Article II means that all executive power is vested in the President) (It is perhaps worth remembering that Justice Scalia's dissent attracted only his own vote.). 
nature..$^{99}$ That power was not vested in Congress; it belonged to the people. So it would not be right to say, without qualification, that "All legislative powers shall be vested in Congress." Another possibility is more practical: the statement "All legislative powers shall be vested in a Congress of the United States" could have been read (or misread) to mean that the state legislatures were being stripped of their legislative powers. The drafters surely wanted neither to convey that idea nor to invite that misreading. Even if the Convention delegates had no intention of ending state-level legislation, they would not have wanted to propose a Constitution whose text would require them to explain that point. "All legislative powers shall be vested in a Congress of the United States" might accordingly have been a distinctly imprudent thing to write-especially at the very beginning of the Constitution.

Understood in either of these ways, the "herein granted" language of the Vesting Clause does reflect a gap between the legislative powers vested in Congress and the complete universe of legislative power within the United States. On the first interpretation, it reflects awareness that Congress lacked the power to authorize or abrogate the Constitution. On the second, it reflects awareness that Congress would coexist with state legislatures. But neither of these interpretations points to the enumerationist reading of the Vesting Clause. So long as the states continued to legislate, and Congress never presumed to abrogate the Constitution or establish another one, the limits requiring the Vesting Clause to include the "herein granted" language (rather than just saying "All legislative powers shall be vested in a Congress ....") would be respected even if Congress exercised some powers not affirmatively specified in the Constitution.

In other words, neither of these explanations for the "herein granted" language suggests that the legislative powers "herein granted" are the sum total of congressional power. And as noted earlier, the status of legislative powers other than those "herein granted" is simply not specified by the text of Article I, Section 1.

99. See Hayburn's Case, 2 U.S. (2 Dall.) 408, 410 n.* (1792) ("The people of the United States have vested in Congress all legislative powers granted in the constitution. They have vested in one supreme court, and in such inferior courts as the Congress shall establish, 'the judicial power of the United States.' It is worthy of remark, that in Congress the whole legislative power of the United States is not vested. An important part of that power was exercised by the people themselves, when they 'ordained and established the constitution."' (quoting the circuit court of the district of Pennsylvania)). 
Maybe Congress has such powers, and maybe it does not, but the Vesting Clause does not decide the issue. What the Vesting Clause says, on the plain-meaning interpretation, is that no one but Congress is vested with the legislative powers herein granted, not that Congress can exercise no powers but those. That is the straightforward meaning of "All legislative Powers herein granted shall be vested in a Congress of the United States."

\section{B. Problems With the Plain-MeAning ReAding}

The plain-meaning reading of the Vesting Clause makes considerably more textual sense than the enumerationist reading. But the plain-meaning reading can also be questioned, because its central contention - that nobody but Congress is vested with legislative powers granted by the Constitution-is open to dispute. For example, within the same Founding-era scheme that understood the Senate's power to try impeachments as judicial and its power over appointments as executive, two powers vested in the President might be classified as legislative. ${ }^{100}$ They are the veto power, ${ }^{101}$ which as a practical matter makes the President the single most powerful person in the legislative process, and the power to make treaties. ${ }^{102}$ If the President exercises legislative power when doing those things, then it would not be true that the

100. At the New York ratifying convention, Hamilton described "legislative authority" under the Constitution as "lodged in three distinct branches properly balanced[.]" The New York Convention, in 22 THE DocumENTARY History OF THE RATIFICATION OF THE CONSTITUTION 1921, 1953 (John P. Kaminski et al. eds., 2008). See also MAIER, supra note 48 , at 151-52, 513 n.79.

101. Blackstone described the monarch under the British constitution as exercising a veto as "a constituent part of the supreme legislative power." 1 WILLIAM BLACKSTONE, COMMENTARIES ON THE LAWS OF ENGLAND 253 (1769). Blackstone can also be read as describing the veto as executive. See id. at 242-43. It may be reasonable to construe Blackstone as taking the position that the veto is both of those things - which, to the extent that Blackstone's scheme is informative as to prominent conceptions among the Founders, would be sufficient to make trouble for the proposition that only Congress can exercise legislative power. Whether under the influence of Blackstone or otherwise, Americans at the Founding did often describe the executive in the British government - that is, the monarch - as wielding legislative as well as executive power. See, e.g., THE FEDERALIST No. 47 (James Madison); 1 ANNALS OF CONG. 553 (1789) (Joseph Gales ed., 1834) (statement of Rep. Jackson) (saying that, in Britain, "the Executive authority is connected with, and forms a part of, the Legislative, and this upon Constitutional ground; it expands itself further, and within its capacious grasp actually holds the Legislative as well as Executive powers").

102. See, e.g., THE Federalist No. 47 (James Madison) (writing that, in Britain, "The executive magistrate forms an integral part of the legislative authority. He alone has the prerogative of making treaties with foreign sovereigns, which, when made, have, under certain limitations, the force of legislative acts."). 
Constitution vests legislative powers only in Congress.

A defender of the plain-meaning interpretation could push back in several ways. For example, one might argue that "vesting" a power means authorizing a party to exercise that power completely, not authorizing that party to participate in the process in which the power is exercised. We do not say, this argument might run, that the power to lay taxes is vested in the House of Representatives, nor in the Senate. It is vested in Congress. On this view, the veto power vests no legislative power in the President. Veto power gives the President influence in the legislative process, but a veto never creates legislation, and nothing the President does can create legislation without the consent of Congress. ${ }^{103}$ In contrast, Congress - in which legislative powers are vested-can legislate without the President if he declines to act, or over his objection with sufficient supermajorities. By the same token, the treaty power would also not be "vested" in the President, because the President cannot conclude treaties alone. He needs the approval of the Senate.

That solution to the treaty-power problem generates a new problem for the plain-meaning reading of the Vesting Clause: it prevents the treaty power from being vested in the President, but in a way that entails the conclusion that the treaty power is not vested in Congress either. A treaty, unlike a statute, is not something that Congress can create without the President's participation. So if treaty-making is an exercise of legislative power, the choice to regard a power as "vested" in a decisionmaker only if that decisionmaker can exercise the power unilaterally would not be consistent with the proposition that Congress is vested with all legislative powers granted in the Constitution.

But the defender of the plain-meaning interpretation has responses available. For example, one could push back on the characterization of treaty-making as legislative rather than executive. Both views were available at the Founding, as was the (probably more mature) view that it is neither entirely one thing

103. It is perhaps worthy of observation that when members of the Founding generation characterized the President as having legislative power because of his power within the legislative process, they discussed the power to veto bills rather than the power to approve them, even though it is the power to approve bills that is the power to make law. See, e.g., id. I will be grateful to readers who bring counterexamples to my attention. 
nor entirely the other. ${ }^{104}$ Alternatively, a defender of the plainmeaning interpretation might say that "herein granted" means "granted in Article I," not "granted in the Constitution"-in which case treaty-making is irrelevant, because the treaty power appears in Article II, not in Article I. ${ }^{105}$ One might even deny that the treaty-making power is "granted" by the Constitution at all, on the theory that it was a power already enjoyed by the United States under the Articles of Confederation. ${ }^{106}$

Reasonable people might have varying opinions about whether these responses successfully defend the plain-meaning interpretation of the Vesting Clause. My own sense is that the attractiveness of the plain-meaning interpretation, all things considered, is partly a function of how committed one is to the idea that the difference in syntax between Article I's Vesting Clause and the other Vesting Clauses must reflect something substantive in constitutional law. If the difference in syntax must mean something, then the plain-meaning interpretation is defensible enough to adopt without much worry. It certainly seems more defensible than the enumerationist reading, both because it is more faithful to the Constitution's words and because it is less at odds with Founding-era understandings of what powers were vested in Congress.

\section{THE DRAFTING-PROCESS READING}

\section{A. THE LIMITS OF ClOSE READING}

There is also a third possibility. Perhaps the difference in syntax between the Vesting Clause of Article I and the Vesting Clauses of Articles II and III should not be read to reflect any substantive feature of constitutional law. The reasonable case for this view begins with the recognition that not every tic of language

104. See, e.g., THE Federalist No. 75 (Alexander Hamilton). Whether the President's power in the treaty-making process should be thought of as legislative, executive, or both might depend on a substantive question as well as a conceptual one: different people at the Founding may have had different visions of what the President (or his agents) would actually do during negotiations with foreign governments. The more one imagines the President (or his agents) making substantive decisions about what policies to promote or agree to in treaties, the more the function seems legislative. The more one imagines that the President (or his agents) conducting negotiations within specific policy constraints crafted by Congress, the more the function seems executive.

105. U.S. CONST. art. II, § 2, cl. 2.

106. ARTICLES OF CONFEDERATION OF 1781, art. IX. 
is significant, even in the Constitution. After all, the Constitution is a complex document, drafted by committees and worked over in an even larger group. Anyone who has had the experience of drafting documents under analogous conditions should know that the product, even when good, is unlikely to be tight and elegant in every respect. Even as applied to single-authored documents written by good writers, the assumption that every word choice is careful and significant, or that every clause is written with every other clause in mind, would often yield false inferences. When a document in question is written and edited by committee, those assumptions are even more misplaced. ${ }^{107}$

Moreover, the drafters of the Constitution probably paid less attention to specific choices about wording than later interpreters of the work have. ${ }^{108}$ The practice of reading the text closely for implications and shades of meaning seems to have intensified during the disputations of the ratification process, ${ }^{109}$ with the result that the text was quickly (and has ever since been) subjected to more exacting analyses than it was consciously written to bear. To be sure, it does not follow that we should dismiss close reading as a modality of constitutional decisionmaking or as a tool for understanding the intent of the Framers. Where something seems irregular about enacted language, it makes sense for interpreters to try to figure out whether the irregularity signals something substantive (and if so, what in particular it signals). But sometimes the wisest conclusion, after due investigation, is that nothing substantive depends on a provision's being worded one way rather than another.

Notice that constitutional lawyers' impulse to treat

107. The idea that the Constitution's text can be interpreted on the assumption that every word is there for a reason and that the document's text is something like a perfect system might be, in part, a product of a cultural tendency to venerate the Constitution as divinely inspired. After all, those interpretive conventions are common within some traditional approaches to the interpretation of a different sacred text-the Bible-and some habits of interpretation may carry over from one context to the other. See LEVINSON, supra note 39 (discussing relationships between biblical and constitutional interpretation). But whatever the merits of such interpretive approaches might be in the Biblical context, the Constitution should be understood to be sufficiently unlike the Bible so as to make those approaches unwarranted. For one thing, one of the background assumptions animating the idea that the Bible is properly interpreted as a perfectly spare and elegant document is that the author of the document is perfect and omniscient. Whether it follows that trying to read the Constitution similarly is merely misguided or also idolatrous is a question that different people will answer differently.

108. GIENAPP, supra note 42.

109. Id. at $87-104$. 
differences in phrasing as significant is selective. There are textual anomalies in the Constitution that we glide right by. One of them is even present in the specific context of the three Vesting Clauses. Twenty-first century constitutional lawyers make much of the fact that the phrasing of the Article I Vesting Clause differs from that of the Article II and Article III Vesting Clauses - but the Vesting Clauses of Articles II and III are not fully parallel to each other either, and nobody seems to care. Article II begins "The executive Power shall be vested in a President of the United States." ${ }^{\text {"In }}$ contrast, Article III begins "The judicial Power of the United States, shall be vested in one supreme Court...." 111 Why is the judicial power but not the executive power described as a power "of the United States"? This is not a question that constitutional lawyers worry about, and reasonably not. The difference between the first Clauses of Articles II and III and the first Clause of Article I might be no more significant.

At the time of the Founding-more specifically, from the time that the constitutional text was drafted until Hamilton's first Pacificus letter in 1793-it seems that the difference in phrasing between Article I's Vesting Clause and the Vesting Clauses of Articles II and III was one that readers passed over with as little thought as is now given to the nonparallel phrasing of the latter two Vesting Clauses. Not only is there virtually no evidence that readers considered the distinctive phrasing of Article I's Vesting Clause significant, but there are several recorded instances of well-informed readers speaking affirmatively as if the three Vesting Clauses were fully parallel. In the removal debate, for example, Richard Bland Lee is recorded as saying that the Constitution creates "three principal branches, with express declarations, that all Legislative power shall vest in one, all Executive in another, and the whole Judicial in a third." 112 It is common, of course, for even generally competent readers to describe a proposition as "express" in the Constitution even when

110. U.S. CONST. art. II, $\S 1$, cl. 1 .

111. Id. art. III, $\S 1$.

112. 1 ANNALS OF CONG. 525 (1789) (Joseph Gales ed., 1834) (statement of Rep. R.B. Lee). Lee was, of course, a member of Virginia's Lee dynasty: he was the cousin of Richard Henry Lee, the brother of General Henry ("Light-Horse Harry") Lee and General (later Attorney General) Charles Lee, and the uncle of Robert E. Lee. See generally PETER STONE \& SHERMAN EDWARDS, The Lees of Old Virginia, in 1776: A Musical Play 10, 10-19 (1976) (1969). In the House of Representatives, Lee represented the portion of Virginia that included Mount Vernon, which made President Washington his constituent. 
the words of the Constitution do not state that proposition. ${ }^{113}$ But they generally do so when the meaning they attribute to the Constitution is well within prevailing expectations about what the Constitution directs. If the Founders generally thought that Article I's Vesting Clause was worded differently from the other two Vesting Clauses so as to make the point that Congress was vested with less than all legislative power, Members of Congress probably would not have asserted that "all Legislative power" was vested in Congress just as all executive power is vested in the President-let alone that the arrangement was directed by "express declarations." ${ }^{114}$ Similarly, and again in the removal debate, Alexander White argued that deeming the President to enjoy all executive power that the Constitution did not specifically except would also mean that Congress enjoyed all legislative power that the Constitution did not specifically except. ${ }^{115}$ No properly socialized modern constitutional lawyer would make this statement, because the modern lawyer knows to read the difference in the two Vesting Clauses to mean that Congress and the President are different in just this way. In 1789, that proposition was not apparent.

\section{B. MAKing THE SAUSAGE}

Attention to the Constitution's drafting history suggests that the nonparallel phrasing of the three Vesting Clauses may have come about for reasons having nothing to do with distinctive limits on congressional power. ${ }^{116}$ The Convention's first draft of a

113. Cf. LESSIG, supra note 6, describing the enumerationist reading of Article I, Section 1 as "explicitly clear."

114. The Annals of Congress are not a stenographic transcript of the proceedings, so one cannot be certain that the words as they appear in that source were exactly the words spoken on the floor of Congress. But if Lee did not actually use these words, this passage from the Annals would still suggest that asserting that the Constitution "expressly" vested "all Legislative power" in Congress was not a sufficiently bizarre statement so as to prevent the compilers of the Annals from rendering Lee's speech that way (If the notes from which the Annals were compiled seemed to indicate that Lee had said that Congress had three branches rather than two, the compilers might have paused to make sure they hadn't garbled Lee's remarks.).

115. See also 1 ANNALS OF CONG. 513-14 (1789) (Joseph Gales ed., 1834) (statement of Rep. White) (arguing that the relationship between Congress and the legislative power is the same as the relationship between the President and the executive power). In the first two Congresses, White represented a portion of western Virginia that now lies within the state of West Virginia. He subsequently served, at President Washington's appointment, as one of the three commissioners on the board charged with planning the nation's new capital city in the District of Columbia.

116. The account that follows is partly inspired by material discussed in John Mikhail, 
full proposed Constitution was presented by the Committee of Detail on August 6, $1787 .{ }^{117}$ Article I of that draft, in its entirety, said that "The stile of the [] Government shall be, 'The United States of America." "118 Article II, also in its entirety, declared that "The Government shall consist of supreme legislative, executive, and judicial powers." 119 Article III then turned to the discussion of specific institutional arrangements, beginning with the words "The legislative power shall be vested in a Congress[.]" was no mention of powers "herein granted." Congress's Vesting Clause was, in that respect, perfectly parallel to the subsequent vesting clauses for the President ("The Executive Power of the United States shall be vested in a single person.") ${ }^{121}$ and the courts ("The Judicial Power of the United States shall be vested in one Supreme Court, and in such inferior Courts as shall ... be constituted by the Legislature of the United States."). ${ }^{122}$

This draft lay before the Convention from August 6 to September 12. Most of the Convention's discussions of specific congressional powers took place during that time. ${ }^{123}$ While those discussions occurred, nothing in the proposed constitutional text suggested that Congress was getting a smaller share of "the legislative power" than the other branches were getting of "the executive power" and "the judicial power." So far as appears from the surviving records, no one objected to the parallel formulations. No one suggested that the legislative Vesting Clause needed to be changed to say that Congress had only the powers "herein granted," nor that it should be changed in any other way that would reflect a choice to limit Congress to the subsequently specified powers only.

In September, the Committee of Style turned the August 6 draft into something close to the constitutional text that was ultimately adopted. ${ }^{124}$ Among other changes, it eliminated the

\footnotetext{
The Necessary and Proper Clauses, 102 GEO. L.J. 1045, 1100, 1104 (2014).

117. 2 THE RECORDS OF THE FEDERAL CONVENTION OF 1787, at 177 (Max Farrand ed., 1911).

118. Id.

119. Id.

120. Id.

121. Id. at 185

122. Id. at 186.

123. See, e.g., id. at 303-13, 321-24, 337-39, 354-64, 447-56, 497, 508-10.

124. See, e.g., William Michael Treanor, The Case of the Dishonest Scrivener: Gouverneur Morris and the Creation of the Federalist Constitution, 119 MICH. L. REV. (forthcoming) (describing the work of the Committee of Style).
} 
prior draft's first two Articles. ${ }^{125}$ Article III thus became Article I by default. But Article III had not been written to be the document's opening article. It had been written to follow the two introductory articles that were now gone - the ones declaring that "The stile of the Government shall be, 'The United States of America" and that "The Government shall consist of the supreme legislative, executive, and judicial powers." Without those two articles, the first words of what would now be Article I- "The legislative power"-would have no antecedent reference. The Committee of Detail's draft flowed: Article I introduced the government, Article II stated that that government would have a legislative power, and Article III explained where that legislative power would be vested. To instead jump right in with a sentence about some heretofore unmentioned thing called "the legislative power" may have seemed awkward. Changing the language to read "All legislative Powers herein granted shall be vested ..." might have been nothing more than the draftsman's solution to that problem: it let the new Article I begin with a more introductory flavor. If so, and given that virtually nobody in the ratification debates or the First Congress treated the Vesting Clause's distinctive wording as significant, it seems reasonable to think that the Clause's syntax is better explained as an artifact of the drafting process than as the reflection of some substantive commitment about the limited power of Congress.

If that origin story is reasonably accurate - and I do not claim to have done more than make it plausible - then it would be reasonable to understand the Vesting Clauses in either of two

125. One can speculate about why those Articles were eliminated. One possibility is that they were simply casualties of the Committee of Style's larger decision to reduce the number of Articles. The draft produced by the Committee of Detail had twenty-three articles; the Committee of Style returned a slightly shorter document with only seven. Substantively, perhaps the Committee thought that the first two Articles of the prior draft were too provocative when read in comparison with the first two Articles of the Articles of Confederation. The first Article of the Articles of Confederation read "The Stile of this Confederacy shall be "The United States of America." Article I in the Committee of Detail's draft changed "Confederacy" to "Government," thus suggesting rather plainly that the new arrangement was more than "confederated." Article II in the Articles of Confederation read "Each state retains its sovereignty, freedom and independence, and every power, jurisdiction, and right, which is not by this confederation expressly delegated to the United States, in Congress assembled." ARTICLES OF CONFEDERATION OF 1781, art. II. Replacing that language with "The Government shall consist of the supreme legislative, executive, and judicial powers" would have been a pretty bold statement. But this possibility is speculative: existing records do not explain the choice. 
ways. First, they might be best understood not as operative provisions whose texts are finely crafted to allocate power in distinctive ways but as topic sentences for the first three Articles. On this reading, Article I, Section I just means "Now we're going to talk about Congress, which is generally in the legislation business," and the first sections of Articles II and III mean the same thing, mutatis mutandis, for the President and the courts. Alternatively, the Vesting Clauses might do a bit more than introduce the branches: they might introduce the branches and say, substantively, that each branch is the normal or default exerciser of a certain kind of power. But on either reading, it is a mistake to think that the difference in syntax between Article I and the other Articles means that anything distinctive is happening in Article I.

\section{CONCLUSION}

Within the practice of American constitutional law, it is perfectly normal to read clauses to mean things that the drafters and ratifiers would not have expected. ${ }^{126}$ But the recognition that the Convention probably did not mean to signal anything substantive by writing "All legislative Powers herein granted shall be vested ..." rather than "The legislative power shall be vested..." might make it easier for constitutional lawyers to question the claim that the wording directs us to take a particular attitude toward the limits of congressional power. When one also recognizes that the words of the Clause do not say that Congress is vested only with the legislative powers herein granted, the case for the enumerationist reading of the Clause becomes quite thin. At most, it is an idea hung on a clause, rather than an idea that fidelity to the text requires.

Reading closely is an important part of legal interpretation. It is appropriate for constitutional decisionmakers to notice that the wording of Article I's Vesting Clause is not parallel to that of the other Vesting Clauses and to ask whether something substantive follows. Indeed, it is more than appropriate; it is an exercise of basic competence in constitutional interpretation. But

126. See, e.g., New York v. United States, 505 U.S. 144, 157 (1992) ("The Federal Government undertakes activities today that would have been unimaginable to the Framers .... Yet the powers conferred upon the Federal Government by the Constitution were phrased in language broad enough to allow for the expansion of the Federal Government's role."). 
if one has tried to attribute significance to the difference between two texts and come up only with unsatisfying possibilities, it may be wise to conclude that the textual difference should not make a substantive difference in law.

The enumerationist reading of the Vesting Clause reads "all" to mean "only," blinks at the possibility that the Constitution gave Congress powers beyond the "legislative powers herein granted" because it gave Congress powers that are not legislative at all, and attributes to the clause a meaning that nobody in the ratification debates or the First Congress seemed to find there, despite ample opportunity and incentive to do so. The plain-meaning reading is better: readers who would like to attribute substantive significance to the Clause's distinctive syntax could reasonably adopt it. But in the end, the best interpretation of Article I, Section 1 might not try to find meaning at the level of reading word by word. The wording may be a happenstance of drafting, and the sense of the Clause might simply be "Now we're going to talk about Congress, which is, more or less, a legislature." On either that conception or the plain-meaning reading, the Vesting Clause does not support the claim that Congress may exercise only the powers specifically enumerated in the Constitution. That so many leading constitutional lawyers have thought otherwise, even to the point of thinking the proposition "explicitly clear," 127 is a testament to the power that orthodox thinking about enumerated powers has to shape - and distort - the reading of the Constitution.

127. LESSIG, supra note 6 , at 75 . 